Rose, J.M. and Audus, K.L. (1998) Receptor-mediated angiotensin II transcytosis by brain mcrovessel endothelial cells. Peptides 19, 1023-1030. PMID: 9700750. Publisher's official version: <http://dx.doi.org/10.1016/S0196-9781(98)00054-0>. Open

Access version: http://kuscholarworks.ku.edu/dspace/.

[This document contains the author's accepted manuscript. For the publisher's version, see the link in the header of this document.]

Paper citation: Rose, J.M. and Audus, K.L. (1998) Receptor-mediated angiotensin II transcytosis by brain mcrovessel endothelial cells. Peptides 19, 1023-1030. PMID: 9700750

Keywords: Angiotensin II transcytosis, Cerebral endothelium, Blood-brain barrier, Brain microvessel endothelial cells

Abstract: ROSE, J. M. AND K. L. AUDUS. Receptor-mediated angiotensin I/ transcytosis by brain microvessel endothelial cells. PEPTIDES _ ( ) 199_. Angiotensin II (Ang II) uptake and transport across monolayers of bovine brain microvessel endothelial cells (BMECs) was demonstrated. Ang II transport was linear up to 2 hours, saturable with a $\mathrm{K}_{\mathrm{m}}$ of $1.7 \mathrm{nM}$, and tended to be polarized with the apical-to-basolateral transport being greater. $\left[{ }^{3} \mathrm{H}\right]$-Ang II transport was found to be inhibited by excess unlabeled Ang II, by the Ang II analog sarathrin, and by the endocytic inhibitor phenylarsine oxide. Ang II-(2-8) and -(3-8) were shown to significantly increase the transport of Ang II. These results demonstrate for the first time the receptor-mediated transcytosis of Ang II across brain microvessel endothelium.

Text of paper:

\title{
RECEPTOR-MEDIATED ANGIOTENSIN II TRANSCYTOSIS BY BRAIN MICROVESSEL ENDOTHELIAL
}

\section{CELLS}

Jayna M. Rose and Kenneth L. Audus ${ }^{1}$

Department of Pharmaceutical Chemistry, The University of Kansas, School of Pharmacy, Lawrence, KS 66047

${ }^{1}$ Correspondence to: Kenneth L. Audus, Department of Pharmaceutical Chemistry, The University of Kansas, 236B Simons 2095 Constant Avenue, Lawrence, Kansas 66047. Phone: (785) 864-3609. Fax:

(785) 864-5736. E-mail: audus@smissman.hbc.ukans.edu

running title: Ang II Transcytosis By Brain Endothelium 
Rose, J.M. and Audus, K.L. (1998) Receptor-mediated angiotensin II transcytosis by brain mcrovessel endothelial cells. Peptides 19, 1023-1030. PMID: 9700750. Publisher's official version: <http://dx.doi.org/10.1016/S0196-9781(98)00054-0>. Open Access version: http://kuscholarworks.ku.edu/dspace/.

\section{INTRODUCTION}

The effective delivery of therapeutic peptides out of the blood to specific extravascular targets remains a major obstacle in the use of these agents in the treatment of disease and underscores the need for understanding the fundamental mechanisms by which macromolecules distribute into and across tissue barriers. Due to the unique properties of the endothelium lining the microvasculature of the brain in particular, the potential treatment of central nervous system disorders with peptides presents a significant challenge (5). This thin, continuous nonfenestrated endothelium with tight intercellular junctions is referred to as the blood-brain barrier (BBB) $(5,8,24)$. Along with tight junctions, the cells also have few pinocytic vesicles, a complex glycocalyx, and significant metabolic capacity. These characteristics make the BBB a very selective layer that excludes most water-soluble substances, including peptides, from entering the central nervous system from the blood $(3,5)$.

Angiotensin II (Ang II) is an endogenous octapeptide that produces a number of physiological actions as a potent vasoconstrictor, stimulator of the release of cardiovascular regulators (e.g., endothelin and prostaglandins), neurotransmitter, and vascular cell growth promoter $(22,25,38)$. A recent study indicates that Ang II triggers internalization-recycling processes that seem to be a fundamental part of the Ang II type $\mathrm{AT}_{1}$ receptor transduction mechanism (26). In addition, receptormediated endocytosis of Ang II itself occurs in a number of different cell types $(6,17,19,34,36)$ and does undergo transcytosis across peripheral endothelial cells (18). Moreover, the in vivo demonstration of receptor-mediated uptake of Ang II by endothelial cells has prompted a hypothesis that internalization of Ang II is a physiological mechanism for clearance and protection of the peptide from endothelial peptidases (35).

Previous work in our laboratory established that Ang II has specific binding sites on primary cultures of bovine brain microvessel endothelial cells (BMECs). Ang II also has typical biological effects 
Rose, J.M. and Audus, K.L. (1998) Receptor-mediated angiotensin II transcytosis by brain mcrovessel endothelial cells. Peptides 19, 1023-1030. PMID: 9700750. Publisher's official version: <http://dx.doi.org/10.1016/S0196-9781(98)00054-0>. Open Access version: http://kuscholarworks.ku.edu/dspace/.

in BMECs including permeability regulation and control of cell growth (11-13). We have demonstrated the expression of $\mathrm{AT}_{1}$ receptors on BMECs and that uptake and passage of Ang II across these cells can be blocked by the $\mathrm{AT}_{1}$ antagonist, losartan, but not an $\mathrm{AT}_{2}$ antagonist (27). Moreover, it appears that Ang II remains intact on uptake and transcellular processing by BMECs $(2,12,28)$. On the basis of this background, the objective of this study was to develop evidence as to whether the transport of Ang II across BMEC monolayers was due to a receptor-mediated transcytotic process. This information adds to the pharmaceutical field's knowledge base on transport mechanisms perhaps applicable to the design of future therapeutic peptides and their delivery into the central nervous system, and contributes to our fundamental understanding of the mechanisms regulating vascular levels of peptide hormones.

\section{METHODS}

\section{Chemicals}

$\left[{ }^{3} \mathrm{H}\right]$-Angiotensin II ([3 $\left.\mathrm{H}\right]$-Ang II), specific activity $45 \mathrm{Ci} / \mathrm{mmol}$, was purchased from Amersham (Arlington Heights, IL). Unlabeled Ang II, Ang II-(1-7), Ang II-(2-8), Ang II-(3-8), and sarathrin, and endocytic inhibitors chloroquine, monensin, and phenylarsine oxide, were purchased from Sigma Chemical Company (St. Louis, MO). All other compounds used were of the highest commercially available quality.

\section{Cell Culture}

BMECs were isolated from gray matter of cerebral cortices by enzymatic digestion and subsequent centrifugation, and seeded into primary culture as detailed by Audus et al. (4). This method has been previously characterized as reported in literature $(4,7)$. Isolated BMECs were seeded at a 
Rose, J.M. and Audus, K.L. (1998) Receptor-mediated angiotensin II transcytosis by brain mcrovessel endothelial cells. Peptides 19, 1023-1030. PMID: 9700750. Publisher's official version: <http://dx.doi.org/10.1016/S0196-9781(98)00054-0>. Open Access version: http://kuscholarworks.ku.edu/dspace/.

density of 50,000 cells $/ \mathrm{cm}^{2}$ into culture plates or $100 \mathrm{~mm}$ culture dishes (Corning Costar Corporation, Cambridge, MA) that were precoated with rat-tail collagen and bovine fibronectin (Sigma Chemical Co.). The culture medium consisted of $45 \%$ minimum essential medium, $45 \%$ F-12 Ham nutrient mixture (Gibco Life Technologies, Grand Island, NY), 10 mM HEPES, pH 7.4, 13 mM sodium bicarbonate, $10 \%$ platelet-depleted equine serum, $100 \mu \mathrm{g} / \mathrm{ml}$ heparin, $100 \mu \mathrm{g} / \mathrm{ml}$ streptomycin, $100 \mu \mathrm{g} / \mathrm{ml}$ penicillin $\mathrm{G}, 50$ $\mu \mathrm{g} / \mathrm{ml}$ polymyxin B, and $2.5 \mu \mathrm{g} / \mathrm{ml}$ amphotericin B (Sigma Chemical Co.). The cells were cultured at $37^{\circ} \mathrm{C}$ with $95 \%$ humidity and $5 \% \mathrm{CO}_{2}$. Cells were fed on the third day after seeding and then every other day until confluent monolayers were formed (10-14 days).

\section{Angiotensin II Internalization}

Total Ang II binding and uptake was studied at $37^{\circ} \mathrm{C}$ using confluent monolayers grown in $12-$ well plates. A pulse of $\left[{ }^{3} \mathrm{H}\right]$-Ang II dissolved in culture medium containing serum was added to each well at selected times between 15 minutes and 2 hours. At the conclusion of the experiment, the medium was aspirated from each well and the wells were rinsed three times with $4^{\circ} \mathrm{C}$ culture medium. The cell monolayers were solubilized by the addition of $1.0 \mathrm{ml}$ of $0.2 \mathrm{~N} \mathrm{NaOH} /$ Triton X-100. The lysate was collected, placed in a scintillation vial with $10 \mathrm{ml}$ of scintillation cocktail, and assayed with a Beckman LS 6800 scintillation counter. To obtain the amount of internalized Ang II, the uptake of the peptide by BMECs at $4^{\circ} \mathrm{C}$, a temperature at which only binding occurred (12), was determined as above and subtracted from the $37^{\circ} \mathrm{C}$ data.

Angiotensin II Transendothelial Permeability 
Rose, J.M. and Audus, K.L. (1998) Receptor-mediated angiotensin II transcytosis by brain mcrovessel endothelial cells. Peptides 19, 1023-1030. PMID: 9700750. Publisher's official version: <http://dx.doi.org/10.1016/S0196-9781(98)00054-0>. Open Access version: http://kuscholarworks.ku.edu/dspace/.

Polycarbonate membranes (13 mm diameter; pore size $0.4 \mu \mathrm{m}$ ) were placed into $100 \mathrm{~mm}$ tissue culture dishes and coated with rat-tail collagen and bovine fibronectin. BMECs were grown to confluent monolayers, as determined by inspection of the areas around the membranes using an inverted microscope. The basolateral side of the cells was defined as the side facing the collagen matrix. After confluent monolayers were formed, the membranes were placed in a horizontal Side-bi-Side ${ }^{\mathrm{TM}}$ diffusion apparatus (Crown Glass, Inc., Somerville, NJ) for transendothelial permeability studies. The area of the diffusion membrane was $0.636 \mathrm{~cm}^{2}$. The donor and receiver chambers were filled with $3.0 \mathrm{ml}$ of culture medium and the temperature was maintained with an external circulating water bath. The contents of each chamber were stirred with Teflon coated magnetic stir bars at a speed of $600 \mathrm{r} / \mathrm{min}$ driven by an external drive console (Crown Glass, Inc.).

The apical-to-basolateral permeation of $\left[{ }^{3} \mathrm{H}\right]$-Ang II was studied for 2 hours at $4^{\circ} \mathrm{C}$ and $37^{\circ} \mathrm{C}$ across confluent monolayers and at $37^{\circ} \mathrm{C}$ across collagen-coated membranes. The concentrationdependence of permeation was studied by adding to each donor chamber an aliquot of unlabeled Ang II mixed with [ ${ }^{3} \mathrm{H}$ ]-Ang II. An aliquot of $25 \mu$ l was removed from the donor chamber to be assayed for initial donor concentration. Sample aliquots of $100 \mu$ l were removed from the receiver chamber at various times and the volume was replaced with fresh culture medium. The samples were placed in a scintillation vial with $10 \mathrm{ml}$ of scintillation cocktail and assayed by scintillation spectrometry. The flux was determined by plotting pmoles versus minutes.

The apical-to-basolateral and the basolateral-to-apical permeation of $3 \mathrm{nM}\left[{ }^{3} \mathrm{H}\right]$-Ang II was studied at $37^{\circ} \mathrm{C}$. Samples were taken as described above. The flux was determined by plotting pmoles Ang II appearing in the receiver chamber versus minutes. The apparent permeability coefficient was calculated using the equation:

$$
P=\text { Flux } /\left(A^{*} C_{D o}\right)
$$


Rose, J.M. and Audus, K.L. (1998) Receptor-mediated angiotensin II transcytosis by brain mcrovessel endothelial cells. Peptides 19, 1023-1030. PMID: 9700750. Publisher's official version: <http://dx.doi.org/10.1016/S0196-9781(98)00054-0>. Open Access version: http://kuscholarworks.ku.edu/dspace/.

where flux is the slope of the line, $A$ is the area of the membrane, and $C_{D o}$ is the initial donor concentration (1). The donor concentration did not change by more than $10 \%$ during the time period of these experiments.

Effect of Unlabeled Angiotensin II Peptides on [3 H]-Angiotensin II Uptake and Transport

The effect of unlabeled Ang II, an Ang II peptide antagonist (sarathrin; [Sar ${ }^{1}$, $\left.{ }^{2} r^{8}\right]$-Ang II), or Ang II peptide fragments (Ang II-(1-7); Ang II-(2-8) or Ang III; and Ang II-(3-8) or Ang IV) on the uptake of [ $\left.{ }^{3} \mathrm{H}\right]-$ Ang II was studied on confluent BMEC monolayers grown in 12-well plates. A pulse of $\left[{ }^{3} \mathrm{H}\right]$-Ang II was added to each well along with nM concentrations of unlabeled peptides dissolved in culture medium containing serum. The plates were incubated at $37^{\circ} \mathrm{C}$ for 45 minutes. After the incubation, the monolayers were quickly rinsed three times with $4^{\circ} \mathrm{C}$ culture medium and solubilized as described above. An aliquot of $100 \mu \mathrm{l}$ of lysate was removed to analyze protein content with the BCA protein assay kit (Pierce, Rockford, IL). The remaining lysate from each well was collected, placed in a scintillation vial with $10 \mathrm{ml}$ of scintillation cocktail, and assayed with a Beckman LS 6800 scintillation counter.

The effect of nM concentrations of unlabeled Ang II, sarathrin, Ang II-(1-7); Ang III and Ang IV on the transport of a pulse of $\left[{ }^{3} \mathrm{H}\right]$-Ang II was studied at $37^{\circ} \mathrm{C}$. A pulse of $\left[{ }^{3} \mathrm{H}\right]$-Ang II was added to the donor chamber alone and samples were taken for 30 minutes from the receiver chamber. After the initial 30 minutes, an unlabeled peptide was added to the donor chamber and the transport was followed for 60 additional minutes. Samples were taken as described above. The flux was determined by plotting pmoles versus minutes. The apparent permeability coefficient was calculated using the equation described above. 
Rose, J.M. and Audus, K.L. (1998) Receptor-mediated angiotensin II transcytosis by brain mcrovessel endothelial cells. Peptides 19, 1023-1030. PMID: 9700750. Publisher's official version: <http://dx.doi.org/10.1016/S0196-9781(98)00054-0> . Open Access version: http://kuscholarworks.ku.edu/dspace/.

Effect of Endocytic Inhibitors on $\left[^{3} \mathrm{H}\right]$-Angiotensin II Uptake and Transport

The effect of selected endocytic inhibitors on $\left[{ }^{3} \mathrm{H}\right]$-Ang II was studied on confluent monolayers grown in 24-well plates. A pulse of $\left[{ }^{3} \mathrm{H}\right]$-Ang II was added to each well along with $\mu \mathrm{M}$ concentrations of chloroquine, monensin, or phenylarsine oxide dissolved in culture medium containing serum. The plates were incubated at $37^{\circ} \mathrm{C}$ for 90 minutes. After the incubation, the monolayers were quickly rinsed three times with $4^{\circ} \mathrm{C}$ culture medium and solubilized as described above. The lysate from each well was collected, placed in a scintillation vial with $10 \mathrm{ml}$ of scintillation cocktail, and assayed with a Beckman LS 6800 scintillation counter.

The transport of a pulse of $\left[{ }^{3} \mathrm{H}\right]$-Ang II alone was monitored for 30 minutes at $37^{\circ} \mathrm{C}$ as described above. After the 30 minute sample was removed, an endocytic inhibitor (i.e., $25 \mu \mathrm{M}$ chloroquine or 10 $\mu \mathrm{M}$ monensin or $25 \mu \mathrm{M}$ phenylarsine oxide) was added to the donor chamber and Ang II transport was followed for an additional 60 minutes. Apparent permeability coefficients for Ang II in the presence of the inhibitor were calculated as described above.

\section{Statistical analysis}

The comparison between mean values within each experimental series was performed by oneway analysis of variance using Dunnett's test to compare several treatments against a control.

\section{RESULTS}


Rose, J.M. and Audus, K.L. (1998) Receptor-mediated angiotensin II transcytosis by brain mcrovessel endothelial cells. Peptides 19, 1023-1030. PMID: 9700750. Publisher's official version: <http://dx.doi.org/10.1016/S0196-9781(98)00054-0>. Open Access version: http://kuscholarworks.ku.edu/dspace/.

Total Ang II binding and uptake reached an apparent plateau after 20 minutes (data not shown). The amount of Ang II internalized was found by subtracting the value at $4^{\circ} \mathrm{C}$ from the value at $37^{\circ} \mathrm{C}$, giving a value of $1.4 \times 10^{-12}$ moles (i.e., approximately $0.05 \%$ of the pulse) at 20 minutes, consistent with earlier work in our laboratory (12). By contrast, the apical-to-basolateral permeation of Ang II across BMEC monolayers found to increase linearly with time over a two hour period. Figure 1 shows the transport of Ang II at $4^{\circ} \mathrm{C}, 37^{\circ} \mathrm{C}$, and across collagen-coated polycarbonate membranes in the absence of cells at $37^{\circ} \mathrm{C}$. The presence of the BMEC monolayer on the collagen-coated polycarbonate membrane illustrated the barrier formed by the cell systems to Ang II permeation. The low temperature $\left(4^{\circ} \mathrm{C}\right)$ reduced the transport of Ang II and represented any leakage of the peptide across the monolayers which was not due to cell mediated pathways. By subtracting the $4^{\circ} \mathrm{C}$ data from the $37^{\circ} \mathrm{C}$ data the net permeability was found to be $5 \times 10^{-5} \mathrm{~cm} / \mathrm{sec}$ and represented the transcellular passage of Ang II. The permeation of $3 \mathrm{nM}\left[{ }^{3} \mathrm{H}\right]$-Ang II was also studied across BMEC monolayers in the basolateral-to-apical direction at $37^{\circ} \mathrm{C}$ and the apparent permeability coefficient was $3.5 \times 10^{-5} \mathrm{~cm} / \mathrm{sec}$. While not statistically significant, the trend of a 1.3 to 1.4 fold greater apical-to-basolateral permeation of Ang II across the monolayers was always reproducible.

The concentration dependence of Ang II transport in the apical-to-basolateral direction was performed at $37^{\circ} \mathrm{C}$. Similar data was collected at $4{ }^{\circ} \mathrm{C}$, was subtracted from the $37^{\circ} \mathrm{C}$ data, and the difference plotted as shown in Figure 2. The resulting curve indicated that Ang II transport across BMEC monolayers was a saturable process with a $\mathrm{K}_{\mathrm{m}}$ of $1.7 \mathrm{nM}$. At Ang II concentrations above the saturation point or plateau (>20 nM), peptide transport was found to again increase rapidly and linearly with increasing concentrations (data not shown). 
Rose, J.M. and Audus, K.L. (1998) Receptor-mediated angiotensin II transcytosis by brain mcrovessel endothelial cells. Peptides 19, 1023-1030. PMID: 9700750. Publisher's official version: <http://dx.doi.org/10.1016/S0196-9781(98)00054-0>. Open Access version: http://kuscholarworks.ku.edu/dspace/.

The effect of unlabeled Ang II on [ $\left.{ }^{3} \mathrm{H}\right]$-Ang II transport is shown in Figure 3. For these studies, a pulse of $\left[{ }^{3} \mathrm{H}\right]$-Ang II was added to the donor chamber and samples were taken for 30 minutes. After the 30 minute sample, unlabeled Ang II or an equivalent amount of the peptide's solvent (control) was added to the donor chamber and the receiver samples were taken for an additional 60 minutes. A deflection in the slope was not observed for control experiments (Figure 3). Figures 4A and 4B summarize the statistically significant inhibitory effects of unlabeled Ang II on $\left[{ }^{3} \mathrm{H}\right]$-Ang II internalization by and permeation across BMEC monolayers. Addition of $25 \mathrm{nM}$ sarathrin ([Sar $\left.{ }^{1}{ }^{T_{h}}{ }^{8}\right]$-Ang II), a nonspecific angiotensin II peptide antagonist, also significantly inhibited Ang II apical-to-basolateral transport by approximately $30 \%$ (data not shown).

As illustrated in Figure 5A, a $10 \mathrm{nM}$ concentration of each of the Ang II fragments increased the transport of a pulse of $\left[{ }^{3} \mathrm{H}\right]$-Ang II. The effects seen with Ang II-(1-7) were not significant while both Ang II-(2-8), also known as angiotensin III, and Ang II-(3-8), also known as angiotensin IV, were shown to significantly increase the transport of Ang II across BMEC monolayers. By contrast, internalization studies shown in Figure 5B indicated that only the Ang II-(1-7) fragment significantly enhanced Ang II uptake.

Effect of Endocytic Inhibitors on $\left.{ }^{3} \mathrm{H}\right]$-Angiotensin II Internalization and Transport

Figures $6 \mathrm{~A}, 6 \mathrm{~B}$, and $6 \mathrm{C}$ show the effect of endocytic inhibitors on internalization of $\left[{ }^{3} \mathrm{H}\right]$-Ang II and apical-to-basolateral transport of the peptide by BMECs. Ang II internalization studies revealed that both monensin and phenylarsine oxide inhibited uptake of the peptide with monensin's effects being statistically significant. In transport studies, chloroquine $(25 \mu \mathrm{M})$ and monensin $(10 \mu \mathrm{M})$ had no significant effect on $\left[{ }^{3} \mathrm{H}\right]$-Ang II permeation across BMEC monolayers. However, $25 \mu \mathrm{M}$ phenylarsine oxide was shown to significantly decrease the apical-to-basolateral transport of $\left[{ }^{3} \mathrm{H}\right]$-Ang II. 
Rose, J.M. and Audus, K.L. (1998) Receptor-mediated angiotensin II transcytosis by brain mcrovessel endothelial cells. Peptides 19, 1023-1030. PMID: 9700750. Publisher's official version: <http://dx.doi.org/10.1016/S0196-9781(98)00054-0>. Open Access version: http://kuscholarworks.ku.edu/dspace/.

\section{DISCUSSION}

The characterization of the internalization and transcytosis of endogenous peptide hormones by brain microvessel endothelium can provide a fundamental understanding of the role of peptide transporters at the BBB and the significance of these transport processes in regulating circulating levels of vasoactive peptides in the cerebrovasculature. Our primary objective here was to use an in vitro system to develop an understanding of the mechanisms by which circulating Ang II concentrations are regulated and cleared by the endothelial lining of the cerebrovasculature.

The rate of passage of Ang II across the BMEC monolayers was greater than would be predicted on the basis of molecular weight and comparable to an inert, low molecular weight passive, paracellular permeability marker, sucrose. The apical-to-basolateral transport of $\left[{ }^{3} \mathrm{H}\right]$-Ang II across BMEC monolayers was also found to be linear and more rapid than passage of the peptide from the basolateral-to-apical side of the cells. The relative asymmetry of the permeation of the peptide across the monolayers was consistent with our earlier studies which demonstrated that permeability regulation by Ang II was largely due to an apical membrane associated process (13). Further, the relative polarity of Ang II permeation was consistent with BBB's tendency of a reduced endocytic capability at the abluminal (brain) surface (9) and in good agreement with in vitro Ang II processing by peripheral endothelia (18) and proximal tubule epithelia where the peptide's transport was found to be relatively asymmetric and transcellular in nature (6).

The apical-to-basolateral permeation of Ang II across BMEC monolayers was concentrationdependent and saturable with an apparent $\mathrm{K}_{\mathrm{m}}$ of $1.7 \mathrm{nM}$. The affinity of the carrier is in line with the specific binding $K_{d}$ of $3.1 \mathrm{nM}$ for the cells determined in our laboratory (12) and the $1.22 \mathrm{nM} \mathrm{K}_{\mathrm{d}}$ reported by Speth and Harik (30) for Ang II binding to canine microvessels. In the earlier work, we demonstrated 
Rose, J.M. and Audus, K.L. (1998) Receptor-mediated angiotensin II transcytosis by brain mcrovessel endothelial cells. Peptides 19, 1023-1030. PMID: 9700750. Publisher's official version: <http://dx.doi.org/10.1016/S0196-9781(98)00054-0>. Open Access version: http://kuscholarworks.ku.edu/dspace/.

that Ang II exposure (i.e., 1 to $100 \mathrm{nM}$ ) produced a concentration-dependent decrease in the permeability of paracellular markers, fluorescein, molecular weight 376 , and a fluorescein isothiocyanate-conjugated dextran, molecular weight of 4000 (13). Therefore, while the flux of Ang II itself increases with increasing concentration, the paracellular permeability of the monolayers decreases with increasing concentration of the peptide. Therefore, we believe we have established that Ang II processing across BMEC monolayers occurred through a transcellular pathway.

Saturable, receptor-mediated endocytosis of Ang II has now been described in a number of cell types $(6,17,19,34,35)$. Specifically in endothelia, the absence of significant degradation of internalized Ang II has now been confirmed by both in vitro and in vivo studies. In our laboratory, three separate analytical systems, TLC (12), HPLC with electrochemical detection (28), and HPLC with fluorescence detection (2), have demonstrated that Ang II remains intact under the conditions of both the internalization and transport studies described in this report. Reports for peripheral endothelia (18) and proximal tubule epithelia (6) have also provided observations on the saturable transcellular transport of intact Ang II. However, these in vitro observations also fully support the recent van Kats et al. (35) report which indicated that in vivo, endothelial cell clearance of Ang II through an $\mathrm{AT}_{1}$ receptormediated process seems to serve to protect the peptide from endothelial cell peptidases.

The uptake and transport of radiolabeled Ang II was found to be significantly inhibited by the addition of $\mathrm{nM}$ concentrations of unlabeled Ang II or the Ang II peptide antagonist sarathrin. These findings were in good agreement with similar studies with other cell types $(6,17-19,34,36)$. At concentrations above the plateau (>20 nM), we observed Ang II transport to increase linearly with increasing concentrations (data not shown). This phenomenon is seen with many receptor-mediated endocytic processes where the molecule exhibits an affinity for the endothelial plasma membrane (37). At lower concentrations, the molecule will exhibit endocytic rates that are dependent upon the number 
Rose, J.M. and Audus, K.L. (1998) Receptor-mediated angiotensin II transcytosis by brain mcrovessel endothelial cells. Peptides 19, 1023-1030. PMID: 9700750. Publisher's official version: <http://dx.doi.org/10.1016/S0196-9781(98)00054-0>. Open Access version: http://kuscholarworks.ku.edu/dspace/.

of membrane binding sites, the dissociation constant of these sites, and the rate of ingestion of surface membrane. As the concentration increases the binding sites become saturated and the rate of endocytosis reaches a steady state. At higher concentrations of substrate, the fluid-phase endocytosis component appears thus showing a linear relationship (37). We can not rule out some contributions of fluid-phase endocytosis to Ang II uptake and transcellular permeation, as our lab and others have demonstrated an Ang II-induced fluid-phase endocytosis in bovine (11) and human (31) BMECs. We suppose this nonspecific transport may in fact contribute to the absence of complete inhibition of Ang II internalization and transport in the presence of peptide competitors for receptor binding.

In vivo in the circulation, Ang II is likely to be metabolized and fragments of the peptide can interact with receptor sites. Thus, we examined effects of three prominent fragments on Ang II uptake and transport. The three fragments of Ang II, Ang II-(1-7), Ang III, and Ang IV, all increased the transcellular transport of Ang II across BMEC monolayers. Only Ang II -(1-7) significantly increased the internalization of the parent peptide. Currently, there are four Ang II receptor populations that have been described $(16,29,32)$. Most of the known biological activities of Ang II are believed to be mediated by the $A T_{1}$ receptor (33). Ang II-(1-7) has been shown to have effects that are opposite of Ang II, including inhibition of vasoconstriction and cell growth, which do not appear to be mediated by either the $\mathrm{AT}_{1}$ or $\mathrm{AT}_{2}$ receptor $(10,20,21)$. Ang $\mathrm{II}-(2-8)$ is reported to have activity as a vasoconstrictor, presumably through the $\mathrm{AT}_{1}$ receptor (29). The $\mathrm{AT}_{4}$ receptor, which preferentially binds Ang II-(3-8), has been implicated in memory acquisition and retrieval, and the regulation of blood flow (39). Ang II-(3-8) and Ang II were found to have opposite effects on cerebral blood flow, with Ang II decreasing blood flow and Ang II-(3-8) increasing blood flow (16). Ang II-(3-8) was also implicated as a vasodilator in rat cerebral arteries (15). Considering the disparate actions and affinities of the Ang II fragments for the $\mathrm{AT}_{1}$ receptor, we suggest that the internalization and transport process we observed here were specific to the parent Ang II and the $\mathrm{AT}_{1}$ receptor. In part this supposition is based on our recent work (27) 
Rose, J.M. and Audus, K.L. (1998) Receptor-mediated angiotensin II transcytosis by brain mcrovessel endothelial cells. Peptides 19, 1023-1030. PMID: 9700750. Publisher's official version: <http://dx.doi.org/10.1016/S0196-9781(98)00054-0>. Open Access version: http://kuscholarworks.ku.edu/dspace/.

which demonstrated that an $\mathrm{AT}_{2}$ antagonist did not inhibit the permeation of Ang II across the BMEC monolayers. That work also established with immunoblots, expression of a membrane-associated $\mathrm{AT}_{1}$ receptor (27). Unfortunately, antibodies do not currently exist for the other receptors. The Ang II fragments may either interact with other binding sites that indirectly regulate endocytic processes of BMECs or, alternatively, the fragments may displace Ang II from other non-AT ${ }_{1}$ binding sites, providing more Ang II for specific internalization or transport pathways. Future work will be directed at defining the role of the fragments in binding, controlling fluid-phase endocytosis, and other biological functions in the BMECs.

Receptor-mediated endocytosis and transcytosis as mechanisms for Ang II processing by BMECs was supported by our observations that known endocytic inhibitors, monensin and phenylarsine oxide both inhibited Ang II internalization by BMECs. Phenylarsine oxide also significantly inhibited the transport of Ang II across the BMEC monolayers while monensin and chloroquine had little or no effect on peptide transport. Phenylarsine oxide has been shown to consistently inhibit, at least in part, Ang II internalization and transport in other studies $(6,17)$ and was supported by our observations. Monensin has been shown to effectively inhibit Ang II $\mathrm{AT}_{1}$ receptor internalization and recycling back to the cell surface $(17,26)$ and chloroquine inhibits Ang II dissociation from cells $(17)$. We did not look at Ang II return to the culture medium in this study and chloroquine may, in fact, have had effects on this process by BMECs. We did previously find that chloroquine inhibited Ang II-stimulated fluid-phase endocytosis by BMECs (11) and may be an indication that only certain endosomal pathways of these cell were sensitive to the drug. Although the concentrations of inhibitors used here were within ranges known to affect the internalization and transport of other receptors, the effects of these inhibitors generally differ from cell type to cell type. From earlier work we also know that the activity of apical membrane internalization-recycling activities by BMECs appeared to be quite active while the contributions of transcellular transport were limited $(14,23)$. The differences between effects of the endocytic inhibitors 
Rose, J.M. and Audus, K.L. (1998) Receptor-mediated angiotensin II transcytosis by brain mcrovessel endothelial cells. Peptides 19, 1023-1030. PMID: 9700750. Publisher's official version: <http://dx.doi.org/10.1016/S0196-9781(98)00054-0>. Open Access version: http://kuscholarworks.ku.edu/dspace/.

on internalization and transport could also be due to the differences between experimental conditions in uptake and transport studies. For the internalization studies, Ang II and the inhibitors were added at the same time whereas in the more dynamic transport studies, the inhibitor was added after Ang II was already being processed for transcytosis by the BMECs. Therefore, in the transport studies the more active internalization process allowed Ang II to enter the cell and the intracellular sorting process. Consequently, much of the Ang II transport observed in the presence of the inhibitors was peptide that may have entered the cells prior to addition of the agent. Irregardless, the sensitivity of the internalization and transport of Ang II to monensin and phenylarsine oxide affirmed a role for endosomal processing of the peptide and was consistent with reports for other cell types exhibiting receptor-mediated endocytosis $(17-19,34,36)$.

In conclusion, the permeation of Ang II across BMEC monolayers was linear, concentrationdependent, saturable, tended to be polarized in the apical-to-basolateral direction, and was attenuated by endocytic inhibitors. This study forms the basis to further consider metabolically stable Ang II peptide analogs or Ang II receptor substrates as BBB transport vectors and further supports the role of the BBB as an active participant in regulating vascular levels of peptide hormones.

\section{Acknowledgments}

This work was supported by the American Heart Association - Kansas Affiliate, an AFPE predoctoral fellowship (JMR), a PhRMA predoctoral fellowship (JMR), a Higuchi graduate fellowship (JMR), and an NIGMS predoctoral training program in biotechnology (JMR). The authors gratefully acknowledge the support of Corning Costar for use of the Cellular and Molecular Biopharmaceutics Handling Laboratory. 
Rose, J.M. and Audus, K.L. (1998) Receptor-mediated angiotensin II transcytosis by brain mcrovessel endothelial cells. Peptides 19, 1023-1030. PMID: 9700750. Publisher's official version: <http://dx.doi.org/10.1016/S0196-9781(98)00054-0>. Open

Access version: http://kuscholarworks.ku.edu/dspace/.

\section{REFERENCES}

1. Adson, A.; Raub, T. J.; Burton, P. S.; Barsuhn, C. L.; Hilgers, A. R.; Audus, K. L.; Ho, N. F. H. Quantitative approaches to delineate paracellular diffusion in cultured epithelial cell monolayers. J. Pharm. Sci. 83:1529-1536; 1994.

2. Anderson, J.M.; Wimalasena, R.; Foster, K., et al. Internalization and transport of angiotensin II by bovine brain microvessel endothelial cells (BBMECs). Pharm. Res. 11:S-251; 1994.

3. Audus, K. L. Blood-brain barrier: mechanisms of peptide regulation and transport. J. Controlled Rel. 11:51-59; 1990.

4. Audus, K. L.; Ng, L.; Wang, W.; Borchardt, R. T. Brain microvessel endothelial cell culture systems. In: Borchardt, R. T.; Smith, P. L.; Wilson, G. Eds. Model for assessing drug absorption and metabolism. New York: Plenum Press; 1996;239-258.

5. Banks, W. A.; Kastin, A. J.; Barrera, C. M. Delivering peptides to the central nervous system: dilemmas and strategies. Pharm. Res. 8:1345-1350; 1991.

6. Becker, B. N.; Cheng, H. F.; Burns, K. D.; Harris, R. C. Polarized rabbit type 1 angiotensin II receptors manifest differential rates of endocytosis and recycling. Am. J. Physiol. 269:C1048-C1056; 1995.

7. Bowman, P. D.; Ennis, S. R.; Rarey, K. E.; Betz, A. L.; Goldstein, G. W. Brain microvessel endothelial cells in tissue culture: a model for study of blood-brain barrier permeability. Ann. Neurol. 14:396402; 1983.

8. Brightman, M. W.; Reese, T. S. Junctions between intimately apposed cell membranes in the vertebrate brain. J. Cell Biol. 40:648-676; 1969.

9. Broadwell, R. D. Transcytosis of macromolecules through the blood-brain barrier: a cell biological perspective and critical appraisal. Acta Neuropathol. 79:117-128; 1989. 
Rose, J.M. and Audus, K.L. (1998) Receptor-mediated angiotensin II transcytosis by brain mcrovessel endothelial cells. Peptides 19, 1023-1030. PMID: 9700750. Publisher's official version: <http://dx.doi.org/10.1016/S0196-9781(98)00054-0> . Open Access version: http://kuscholarworks.ku.edu/dspace/.

10. Freeman, E. J.; Chisolm, G. M.; Ferrario, C. M.; Tallant, E. A. Angiotensin-(1-7) inhibits vascular smooth muscle cell growth. Hypertension 28:104-108; 1996.

11. Guillot, F. L.; Audus, K. L. Angiotensin peptide regulation of fluid-phase endocytosis in brain microvessel endothelial cell monolayers. J. Cerebr. Blood Flow Metab. 10:827-834; 1990.

12. Guillot, F. L.; Audus, K. L. Some characteristics of specific angiotensin II binding sites on bovine brain microvessel endothelial cell monolayers. Peptides 12:535-540; 1991.

13. Guillot, F. L.; Audus, K. L. Angiotensin peptide regulation of bovine brain microvessel endothelial cell monolayer permeability. J. Cardiovasc. Pharmacol. 18:212-218; 1991.

14. Guillot, F. L.; Audus, K. L.; Raub, T. J. Fluid-phase endocytosis by primary cultures of bovine brain microvessel endothelial cell monolayers. Microvasc. Res. 39:1-14; 1990.

15. Haberl, R. L.; Decker, P. J.; Einhaupl, K. M. Angiotensin degradation products mediate endotheliumdependent dilation of rabbit brain arterioles. Circ. Res. 68:1621-1627; 1991.

16. Kramar, E. A.; Harding, J. W.; Wright, J. W. Angiotensin II- and IV- induced changes in cerebral blood flow. Roles of $A T_{1}, A T_{2}$, and $A T_{4}$ receptor subtypes. Regul. Pept. 68:131-138; 1997.

17. Lazari, M. F. M.; Porto, C. S.; Freymuller, E.; Abreu, L. C.; Picarelli, Z. P. Receptor-mediated endocytosis of angiotensin II in rat myometrial cells. Biochem. Pharmacol. 54:399-408; 1997.

18. Mineo, C.; Yagyu, Y.; Imanaka, T.; Takano, T. Transcellular transport of angiotensin II through a cultured arterial endothelial monolayer. Exp. Cell Res. 190:99-103; 1990.

19. Montiel, M.; Caro, M. C.; Jimenez, E. Agonist-induced internalisation of the angiotensin II-binding sites from plasma membranes of isolated rat hepatocytes. J. Endocrinol. 152:407-412; 1997.

20. Moriguchi, A.; Tallant, E. A.; Matsumura, K.; Reilly, T. M.; Walton, H.; Ganten, D.; Ferrario, C. M. Opposing actions of angiotensin-(1-7) and angiotensin II in the brain of transgenic hypertensive rats. Hypertension 25:1260-1265; 1995. 
Rose, J.M. and Audus, K.L. (1998) Receptor-mediated angiotensin II transcytosis by brain mcrovessel endothelial cells. Peptides 19, 1023-1030. PMID: 9700750. Publisher's official version: <http://dx.doi.org/10.1016/S0196-9781(98)00054-0> . Open Access version: http://kuscholarworks.ku.edu/dspace/.

21. Nakamoto, H.; Ferrario, C. M.; Fuller, S. B.; Robaczwski, D. L.; Winicov, E.; Dean, R. H. Angiotensin-(17) and nitric oxide interaction in renovascular hypertension. Hypertension 25:796-802; 1995.

22. Phillips, M. I. Functions of angiotensin in the central nervous system. Ann. Rev. Physiol. 49:413-435; 1987.

23. Raub, T. J.; Audus, K. L. Adsorptive endocytosis and membrane recycling by cultured primary bovine brain microvessel endothelial cell monolayers. J. Cell Sci. 97:127-138; 1990.

24. Reese, T. S.; Karnovsky, M. J. Fine structural localization of a blood-brain barrier to exogenous peroxidase. J. Cell Biol. 34:207-217; 1967.

25. Reid, J. L.; Rubin, P. C. Peptides and central neural regulation of the circulation. Physiol. Rev. 67:725749; 1987.

26. Richard, D. E.; Chretien, L.; Caron, M.; Guillemette, G. Stimulation of the angiotensin II type 1 receptor on bovine adrenal glomerulosa cells activates a temperature-sensitive internalizationrecycling pathway. Mol. Cell. Endocrinol. 129:209-218; 1997.

27. Rose, J. M.; Audus, K. L. AT 1 receptors mediate angiotensin II uptake and transport by brain microvessel endothelial cells in primary culture. J. Cardiovasc. Pharmacol., in press, 1998.

28. Rose, M.J.; Lunte, S.M.; Carlson, R.G.; et al. Development of hydroquinone-based derivatization reagents for the quantitation of amines using electrochemical detection. Pharm. Res. 12:S38; 1995.

29. Smith, R. D.; Timmermans, P. B. M. W. M. Ang II receptor antagonists. Pharm. News 4:16-20; 1997.

30. Speth, R. C.; Harik, S. I. Angiotensin II receptor binding sites in brain microvessels. Proc. Natl. Acad. Sci. USA 82:6340-6343; 1985.

31. Stanimirovic, D.; Morley, P.; Ball, R.; Hamel, E.; Mealing, G.; Durkin, J. P. Angiotensin II-induced fluid phase endocytosis in human cerebrovascular endothelial cells is regulated by the inositol-phosphate signaling pathway. J. Cell Physiol. 169:455-467; 1996. 
Rose, J.M. and Audus, K.L. (1998) Receptor-mediated angiotensin II transcytosis by brain mcrovessel endothelial cells. Peptides 19, 1023-1030. PMID: 9700750. Publisher's official version: <http://dx.doi.org/10.1016/S0196-9781(98)00054-0> . Open Access version: http://kuscholarworks.ku.edu/dspace/.

32. Swanson, G. N.; Hanesworth, J. M.; Sardinia, M. F.; Coleman, J. K. M.; Wright, J. W.; Hall, K. L.; MillerWing, A. V.; Stobb, J. W.; Cook, V. I.; Harding, E. C.; Harding, J. W. Discovery of a distinct binding site for angiotensin II (3-8), a putative angiotensin IV receptor. Regul. Pept. 40:409-419; 1992.

33. Timmermans, P. B. M. W. M.; Wong, P. C.; Chiu, A. T.; Herblin, W. F.; Benfield, P.; Carini, D. J.; Lee, R. J.; Wexler, R. R.; Saye, J. M.; Smith, R. D. Angiotensin II receptors and angiotensin II receptor antagonists. Pharmacol. Rev. 45:205-251; 1993.

34. Ullian, M. E.; Linas, S. L. Role of receptor cycling in the regulation of angiotensin II surface receptor number and angiotensin II uptake in rat vascular smooth muscle cells. J. Clin. Invest. 84:840-846; 1989.

35. van Kats, J. P.; de Lannoy, L. M.; Jan Danser, A. H.; van Meegen, J. R.; Verdouw, P. D.; Schalekamp, M. A. D. H. Angiotensin II type $1\left(\mathrm{AT}_{1}\right)$ receptor-mediated accumulation of angiotensin II in tissues and its intracellular half-life in vivo. Hypertension 30:42-49; 1997.

36. Wang, J. M.; Llona, I.; De Potter, W. P. Receptor-mediated internalization of angiotensin II in bovine adrenal medullary chromaffin cells in primary culture. Regul. Pept. 53:77-86; 1994.

37. Williams, S. K. Vesicular transport of proteins by capillary endothelium. Ann. NY Acad. Sci. 416:457$467 ; 1983$.

38. Wright, J. W.; Harding, J. W. Regulatory role of brain angiotensins in the control of physiological and behavioral responses. Brain Res. Rev. 17:227-262; 1992.

39. Wright, J. W.; Harding, J. W. Brain angiotensin receptor subtypes in the control of physiological and behavioral responses. Neurosci. Biobehav. Rev. 18:21-53; 1994. 
Rose, J.M. and Audus, K.L. (1998) Receptor-mediated angiotensin II transcytosis by brain mcrovessel endothelial cells. Peptides 19, 1023-1030. PMID: 9700750. Publisher's official version: <http://dx.doi.org/10.1016/S0196-9781(98)00054-0>. Open Access version: http://kuscholarworks.ku.edu/dspace/.

FIGURE LEGENDS

FIG. 1. Permeation of Ang II across brain microvessel endothelial cell monolayers. Transport was studied on membranes without cell monolayers and on cell monolayers at $4^{\circ} \mathrm{C}$ and $37^{\circ} \mathrm{C}$. A concentration of $3 \mathrm{nM}\left[{ }^{3} \mathrm{H}\right]$-Ang II was used in each donor chamber. Each data point represents the mean $\pm S D(n=3)$.

FIG. 2. Concentration dependence of Ang II flux across brain microvessel endothelial cells in the apicalto-basolateral direction. The data points represent the net permeation (the difference between $37^{\circ} \mathrm{C}$ and $4^{\circ} \mathrm{C}$ data) for Ang II across the BMEC monolayers. Each data point represents the mean difference from triplicate experiments at $4^{\circ} \mathrm{C}$ and $37^{\circ} \mathrm{C}$.

FIG. 3. $\left.{ }^{3} \mathrm{H}\right]$-Ang II permeation across brain microvessel endothelial cells at $37^{\circ} \mathrm{C}$. After monitoring the passage of $\left[{ }^{3} \mathrm{H}\right]$-Ang II across the monolayers for 30 minutes, unlabeled Ang II or the peptide's solvent (control) was added to the donor chamber as a competitor and data was collected for an additional 60 minutes as shown. Control data is represented by the solid line.

FIG. 4. A) Angiotensin II uptake (pulse of $\left[{ }^{3} \mathrm{H}\right]$-Ang II) in brain microvessel endothelial cells alone (shaded bar) and in the presence of $\mathrm{nM}$ concentrations of unlabeled Ang II (hatched bars) for 45 minutes at $37^{\circ} \mathrm{C}$, $\mathrm{pH}$ 7.4. Each bar represents the mean $\pm \mathrm{SD}(\mathrm{n}=4) .{ }^{*}$ represents statistically significant changes $(\mathrm{P}<$ 0.05). B) Apparent permeability coefficients for a pulse of $\left[{ }^{3} \mathrm{H}\right]$-Ang II alone (shaded bar) and in the 
Rose, J.M. and Audus, K.L. (1998) Receptor-mediated angiotensin II transcytosis by brain mcrovessel endothelial cells. Peptides 19, 1023-1030. PMID: 9700750. Publisher's official version: <http://dx.doi.org/10.1016/S0196-9781(98)00054-0>. Open Access version: http://kuscholarworks.ku.edu/dspace/.

presence of unlabeled Ang II (hatched bars) across brain microvessel endothelial cells. Each bar represents the mean $\pm S D(n=3) . *$ Statistically significant changes $(P<0.05) .{ }^{* *}$ Statistically significant changes $(P<0.01)$.

FIG. 5. A) Angiotensin II uptake (pulse of $\left[{ }^{3} \mathrm{H}\right]$-Ang II) in brain microvessel endothelial cells alone (shaded bar) and in the presence of $10 \mathrm{nM}$ Ang II-(1-7), $10 \mathrm{nM}$ Ang II-(2-8), or $10 \mathrm{nM}$ Ang II-(3-8) (hatched bars) for 45 minutes at $37^{\circ} \mathrm{C}, \mathrm{pH} 7.4$. Each bar represents the mean $\pm \mathrm{SD}(\mathrm{n}=4)$. * represents statistically significant changes $(P<0.05)$.

B) Apparent permeability coefficients for a pulse of $\left[{ }^{3} \mathrm{H}\right]$-Ang II alone (shaded bar) and in the presence of 10 nM Ang II-(1-7), 10 nM Ang II-(2-8), or 10 nM Ang II-(3-8) (hatched bars) across brain microvessel endothelial cells. Each bar represents the mean $\pm S D(n=3) . * *$ Statistically significant changes $(P<$ $0.01)$.

FIG. 6. A) Percentage of $\left[{ }^{3} \mathrm{H}\right]$-Ang II uptake in brain microvessel endothelial cells alone (shaded bar) and in the presence of $\mu \mathrm{M}$ concentrations of monensin (hatched bars) for 90 minutes at $37^{\circ} \mathrm{C}, \mathrm{pH} 7.4$. Each bar represents the mean $\pm S D(n=4)$. * represents statistically significant changes $(P<0.05) ; * *$ represents statistically significant changes $(\mathrm{P}<0.01)$. B) Percentage of $\left[{ }^{3} \mathrm{H}\right]$-Ang II uptake in brain microvessel endothelial cells alone (shaded bar) and in the presence of $\mu \mathrm{M}$ concentrations of phenylarsine oxide (hatched bars) for 90 minutes at $37^{\circ} \mathrm{C}, \mathrm{pH} 7.4$. Each bar represents the mean $\pm \mathrm{SD}$ ( $\mathrm{n}$ $=4) .{ }^{*}$ represents statistically significant changes $\left.(P<0.05) . C\right)$ Apparent permeability coefficients for a pulse of $\left[{ }^{3} \mathrm{H}\right]$-Ang II alone (shaded bar) and in the presence of $25 \mu \mathrm{M}$ chloroquine, $10 \mu \mathrm{M}$ monensin, or 
Rose, J.M. and Audus, K.L. (1998) Receptor-mediated angiotensin II transcytosis by brain mcrovessel endothelial cells. Peptides 19, 1023-1030. PMID: 9700750. Publisher's official version: <http://dx.doi.org/10.1016/S0196-9781(98)00054-0> . Open Access version: http://kuscholarworks.ku.edu/dspace/.

$25 \mu \mathrm{M}$ phenylarsine oxide (hatched bars) across brain microvessel endothelial cells. Each bar represents the mean $\pm S D(n=3) . * *$ Statistically significant changes $(P<0.01)$. 
Rose, J.M. and Audus, K.L. (1998) Receptor-mediated angiotensin II transcytosis by brain mcrovessel endothelial cells. Peptides 19, 1023-1030. PMID: 9700750. Publisher's official version: <http://dx.doi.org/10.1016/S0196-9781(98)00054-0> . Open Access version: http://kuscholarworks.ku.edu/dspace/.

Rose and Audus

Figure 1

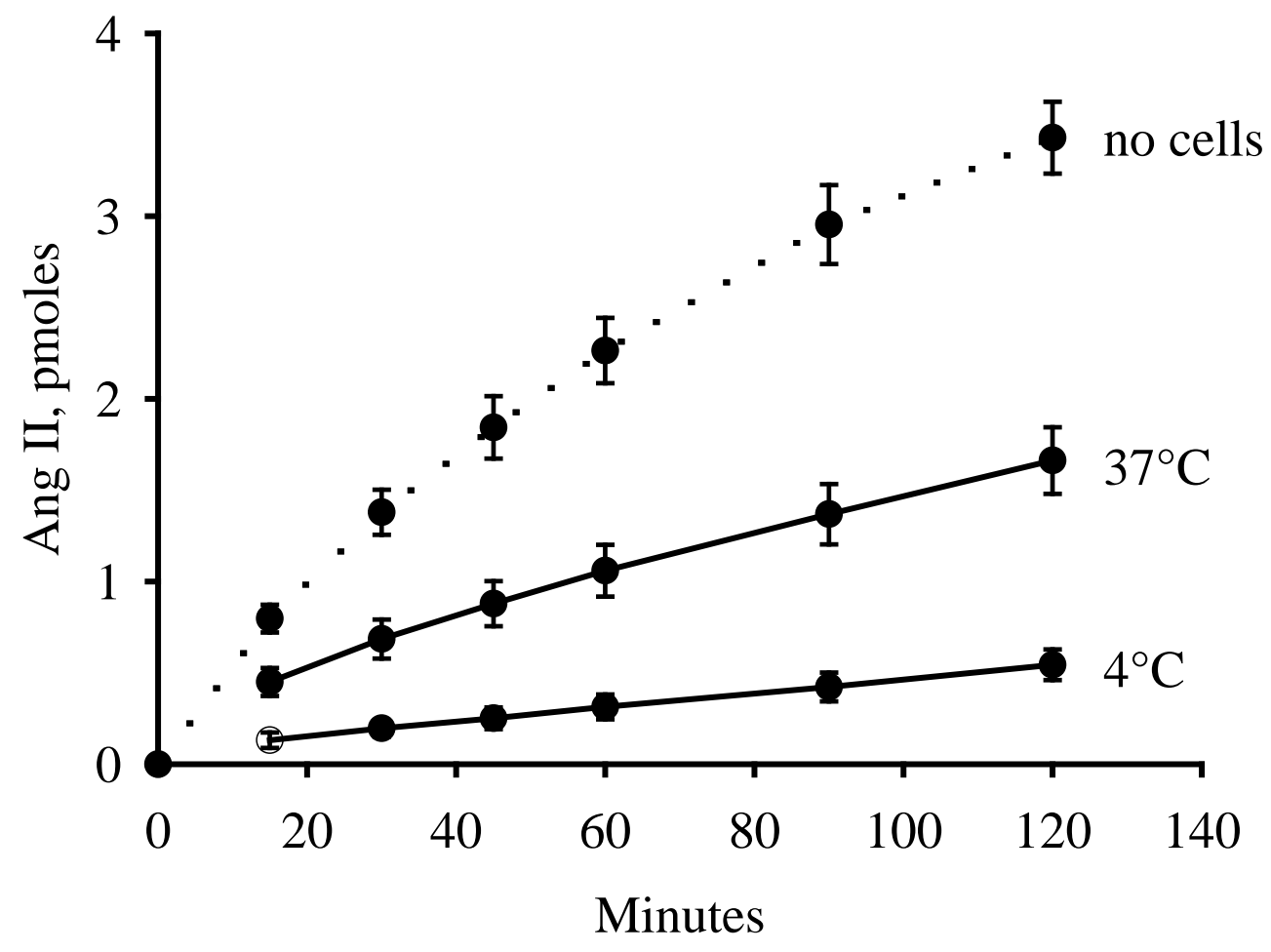


Rose, J.M. and Audus, K.L. (1998) Receptor-mediated angiotensin II transcytosis by brain mcrovessel endothelial cells. Peptides 19, 1023-1030. PMID: 9700750. Publisher's official version: <http://dx.doi.org/10.1016/S0196-9781(98)00054-0> . Open Access version: http://kuscholarworks.ku.edu/dspace/.

Rose and Audus

Figure 2

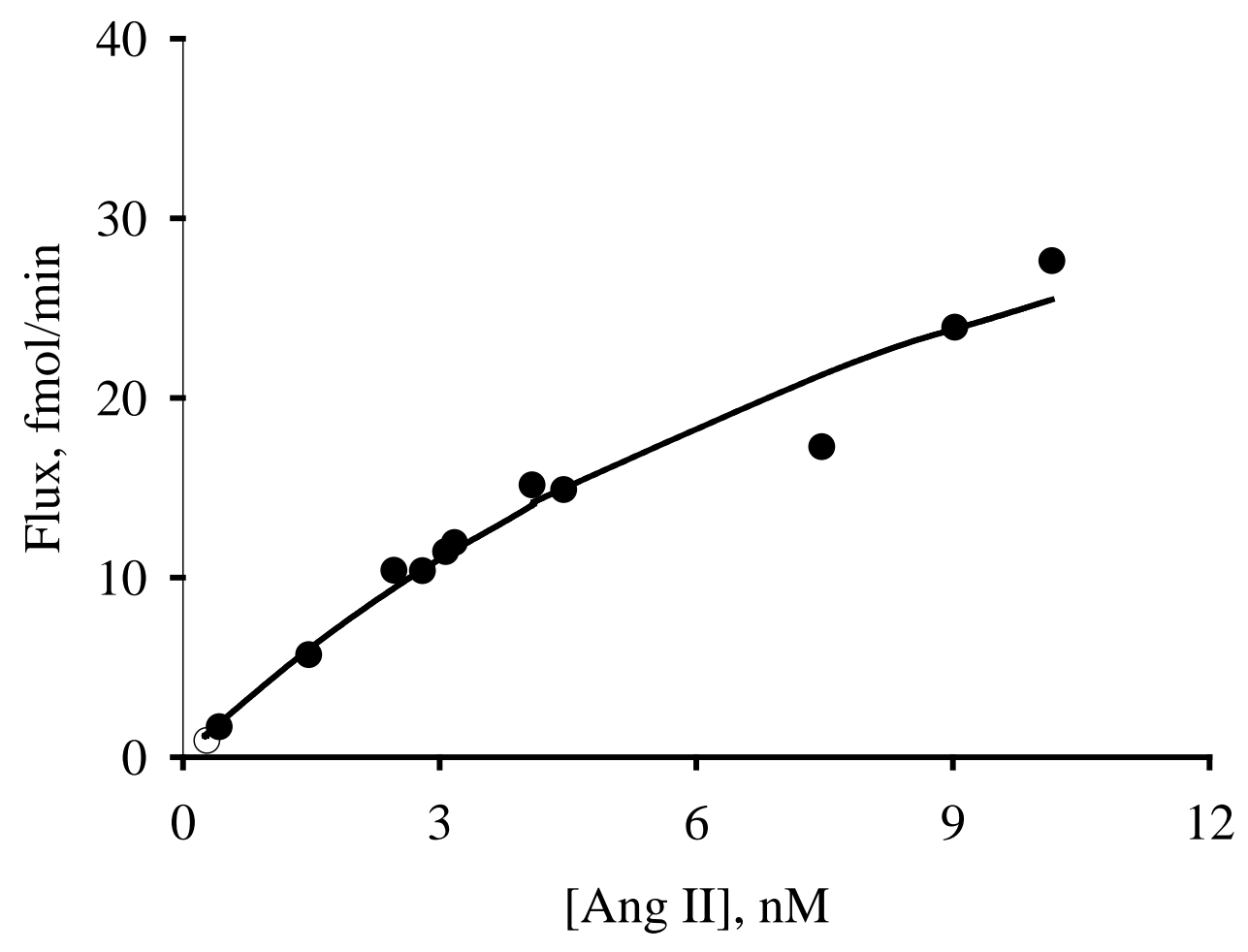


Rose, J.M. and Audus, K.L. (1998) Receptor-mediated angiotensin II transcytosis by brain mcrovessel endothelial cells. Peptides 19, 1023-1030. PMID: 9700750. Publisher's official version: <http://dx.doi.org/10.1016/S0196-9781(98)00054-0> . Open Access version: http://kuscholarworks.ku.edu/dspace/.

Rose and Audus

Figure 3

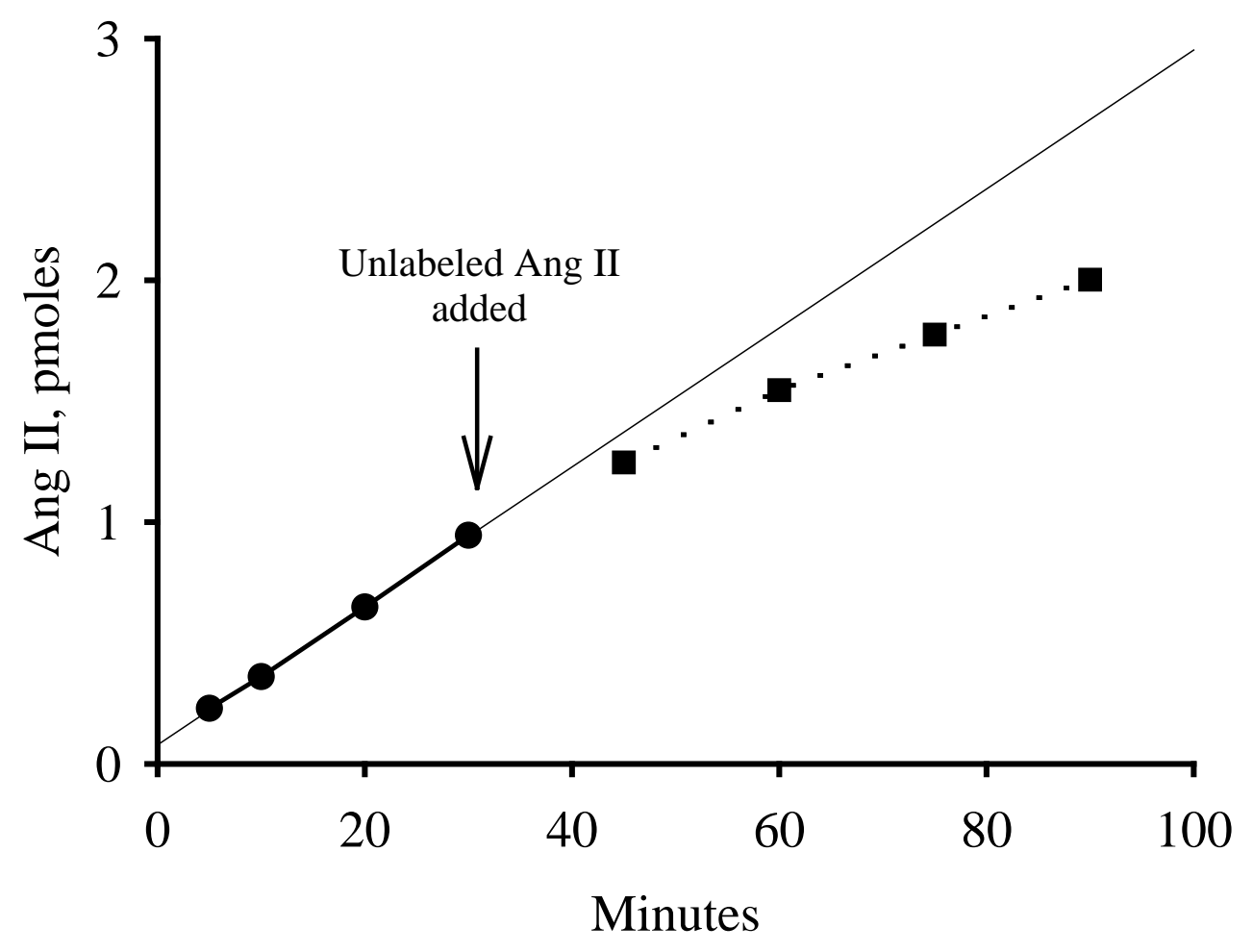


Rose, J.M. and Audus, K.L. (1998) Receptor-mediated angiotensin II transcytosis by brain mcrovessel endothelial cells. Peptides 19, 1023-1030. PMID: 9700750. Publisher's official version: <http://dx.doi.org/10.1016/S0196-9781(98)00054-0> . Open Access version: http://kuscholarworks.ku.edu/dspace/.

Rose and Audus

Figure 4A 
Rose, J.M. and Audus, K.L. (1998) Receptor-mediated angiotensin II transcytosis by brain mcrovessel endothelial cells. Peptides 19, 1023-1030. PMID: 9700750. Publisher's official version: <http://dx.doi.org/10.1016/S0196-9781(98)00054-0> . Open Access version: http://kuscholarworks.ku.edu/dspace/.

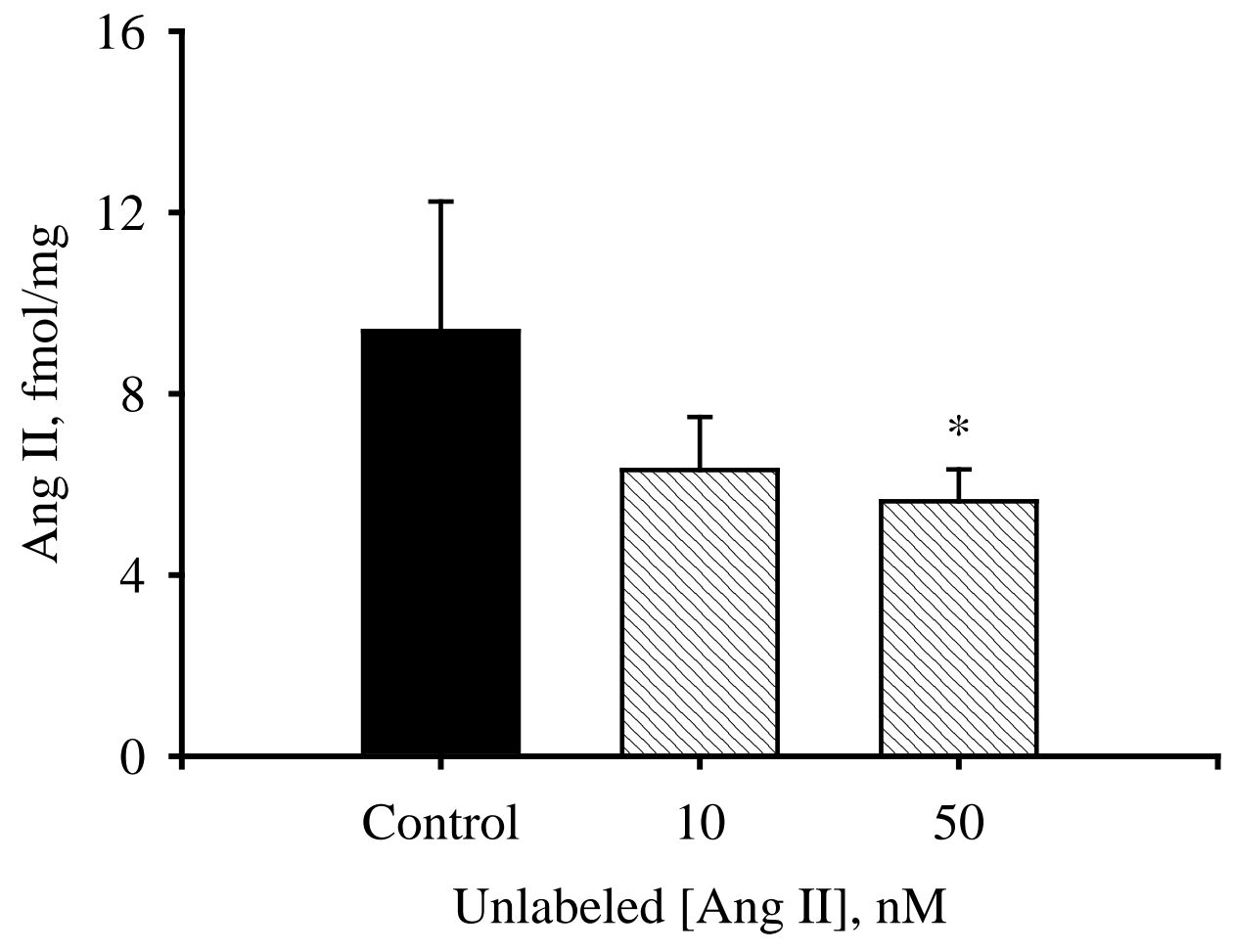

Rose and Audus 
Rose, J.M. and Audus, K.L. (1998) Receptor-mediated angiotensin II transcytosis by brain mcrovessel endothelial cells. Peptides 19, 1023-1030. PMID: 9700750. Publisher's official version: <http://dx.doi.org/10.1016/S0196-9781(98)00054-0> . Open Access version: http://kuscholarworks.ku.edu/dspace/.

Figure 4B

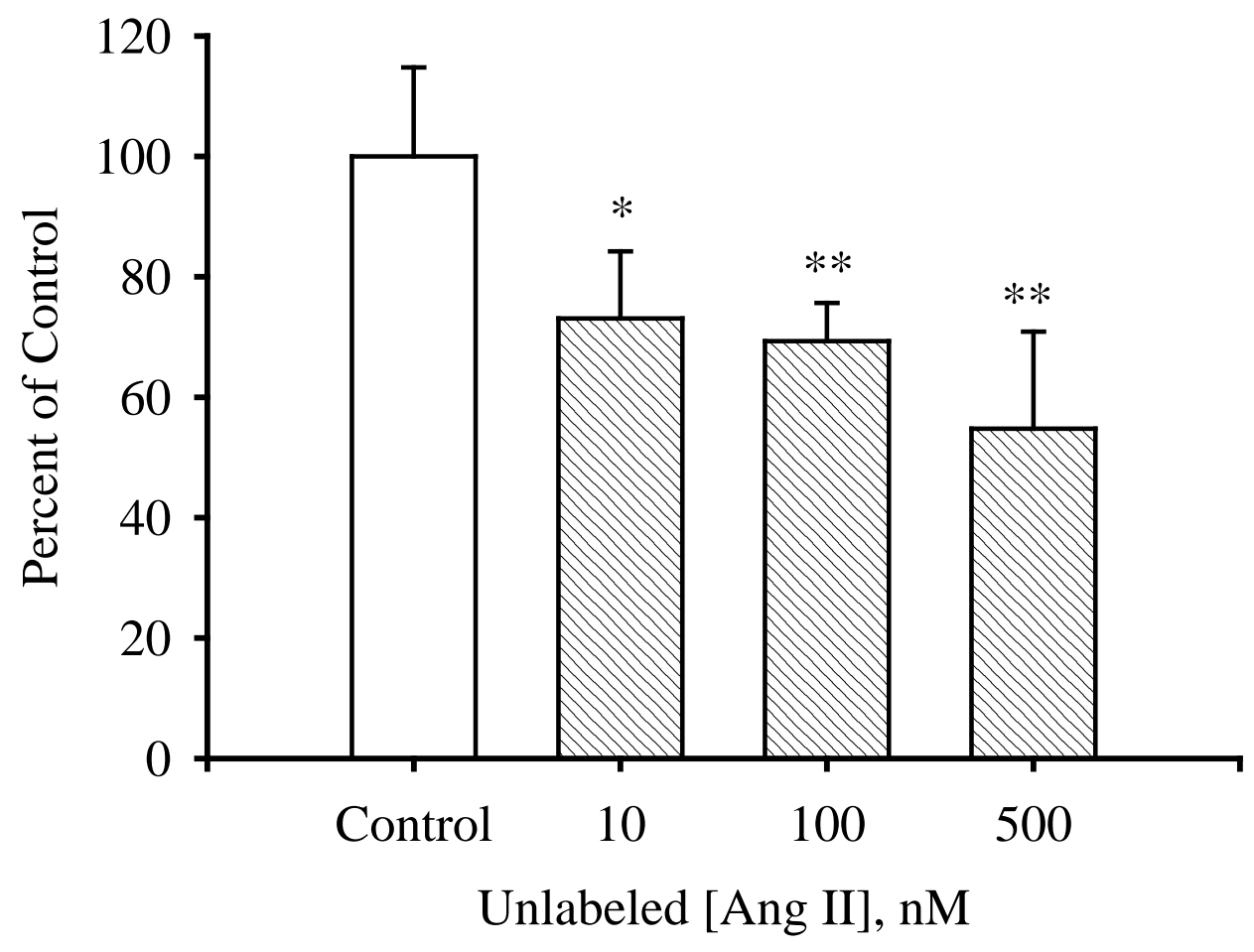


Rose, J.M. and Audus, K.L. (1998) Receptor-mediated angiotensin II transcytosis by brain mcrovessel endothelial cells. Peptides 19, 1023-1030. PMID: 9700750. Publisher's official version: <http://dx.doi.org/10.1016/S0196-9781(98)00054-0> . Open Access version: http://kuscholarworks.ku.edu/dspace/.

Rose and Audus

Figure 5A

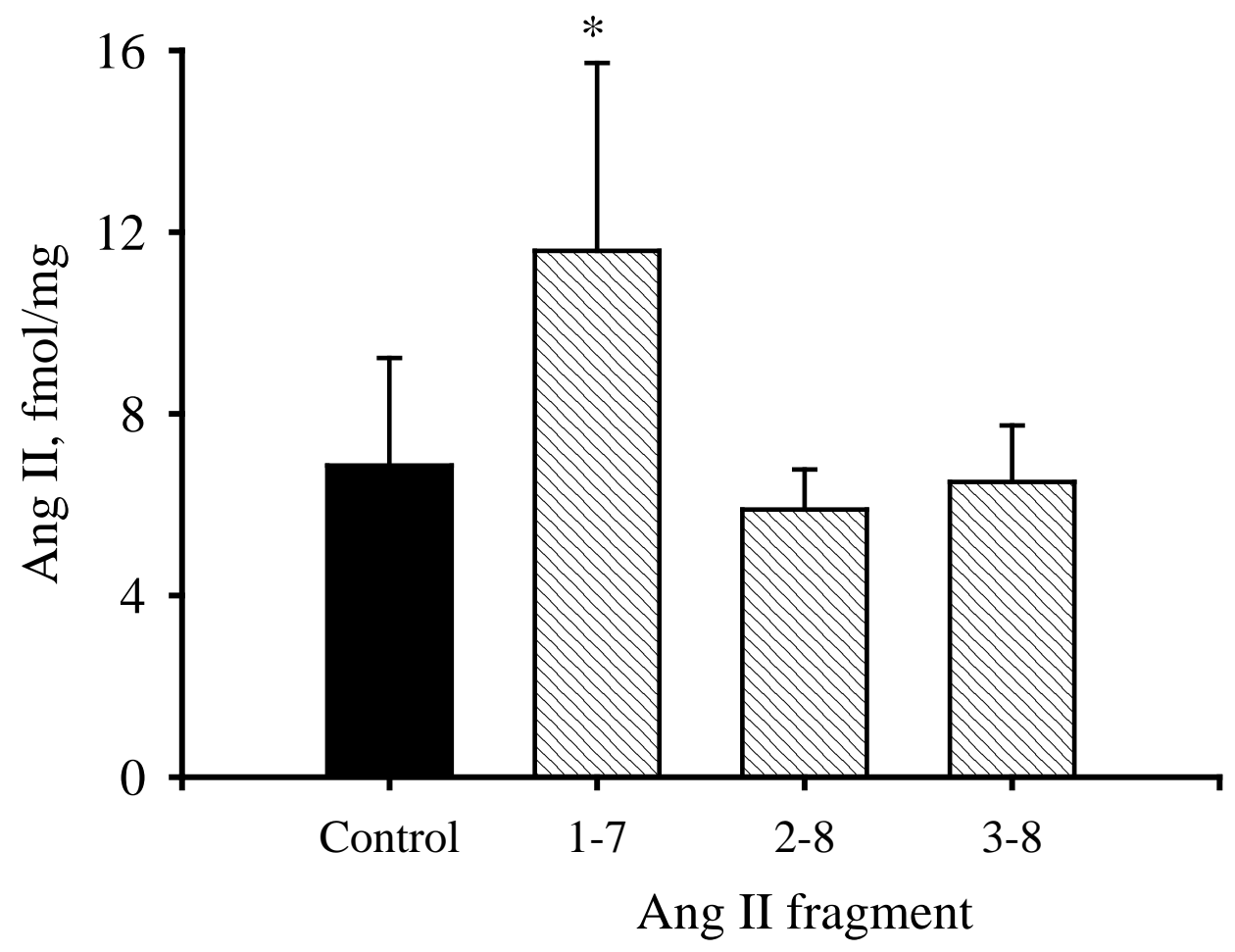


Rose, J.M. and Audus, K.L. (1998) Receptor-mediated angiotensin II transcytosis by brain mcrovessel endothelial cells. Peptides 19, 1023-1030. PMID: 9700750. Publisher's official version: <http://dx.doi.org/10.1016/S0196-9781(98)00054-0> . Open Access version: http://kuscholarworks.ku.edu/dspace/.

Rose and Audus

Figure 5B

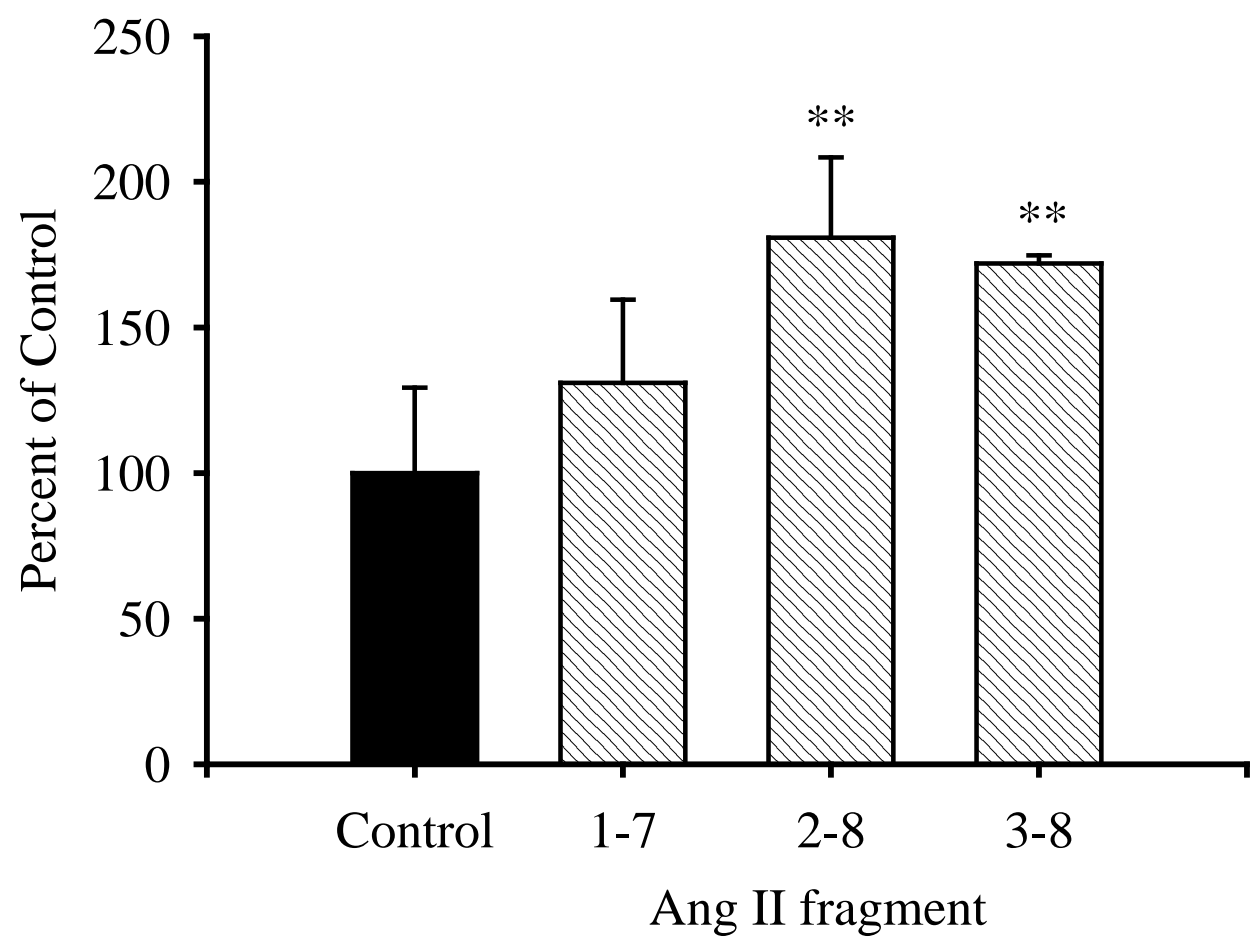


Rose, J.M. and Audus, K.L. (1998) Receptor-mediated angiotensin II transcytosis by brain mcrovessel endothelial cells. Peptides 19, 1023-1030. PMID: 9700750. Publisher's official version: <http://dx.doi.org/10.1016/S0196-9781(98)00054-0> . Open Access version: http://kuscholarworks.ku.edu/dspace/.

Rose and Audus

Figure 6A

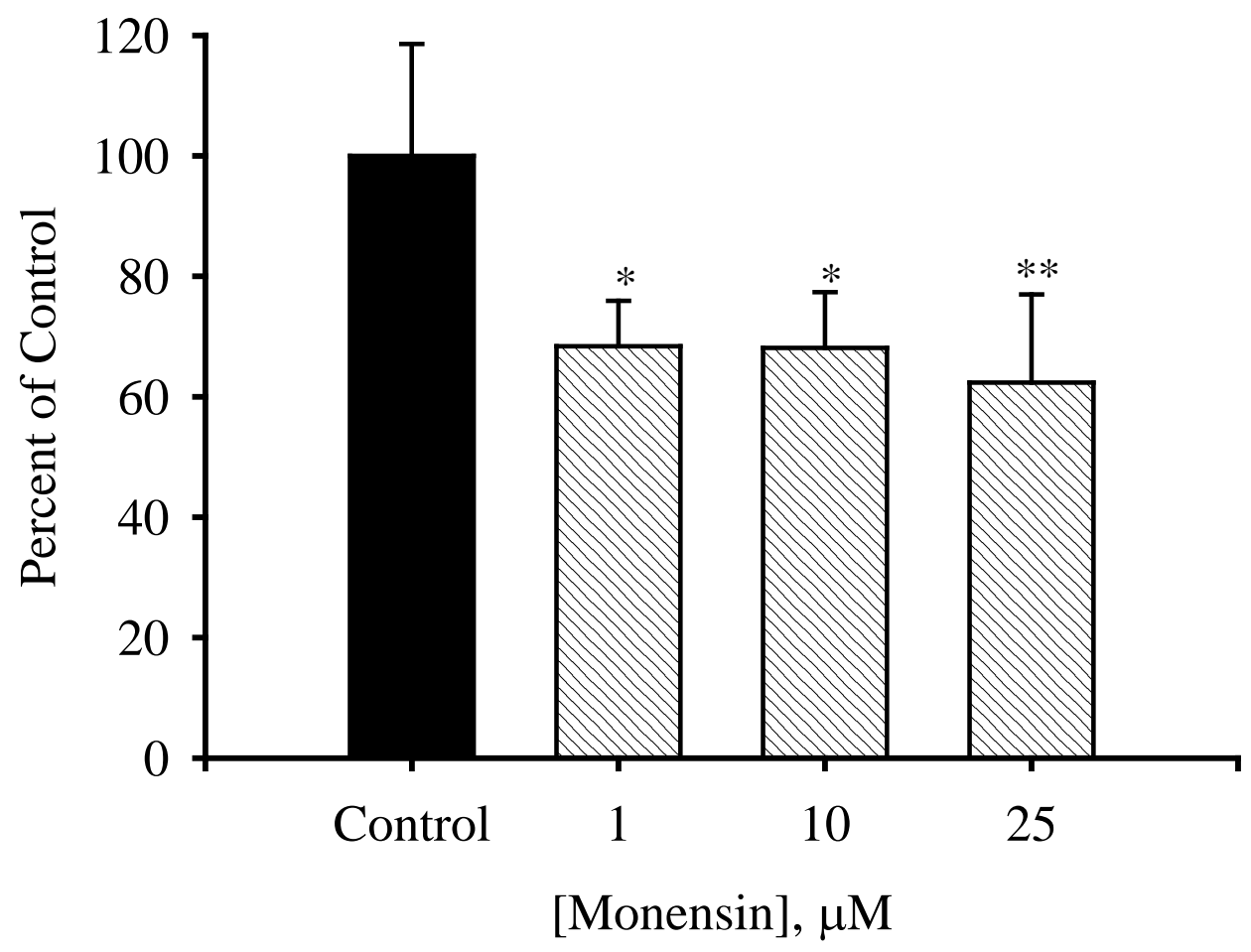


Rose, J.M. and Audus, K.L. (1998) Receptor-mediated angiotensin II transcytosis by brain mcrovessel endothelial cells. Peptides 19, 1023-1030. PMID: 9700750. Publisher's official version: <http://dx.doi.org/10.1016/S0196-9781(98)00054-0> . Open Access version: http://kuscholarworks.ku.edu/dspace/.

Rose and Audus

Figure 6B

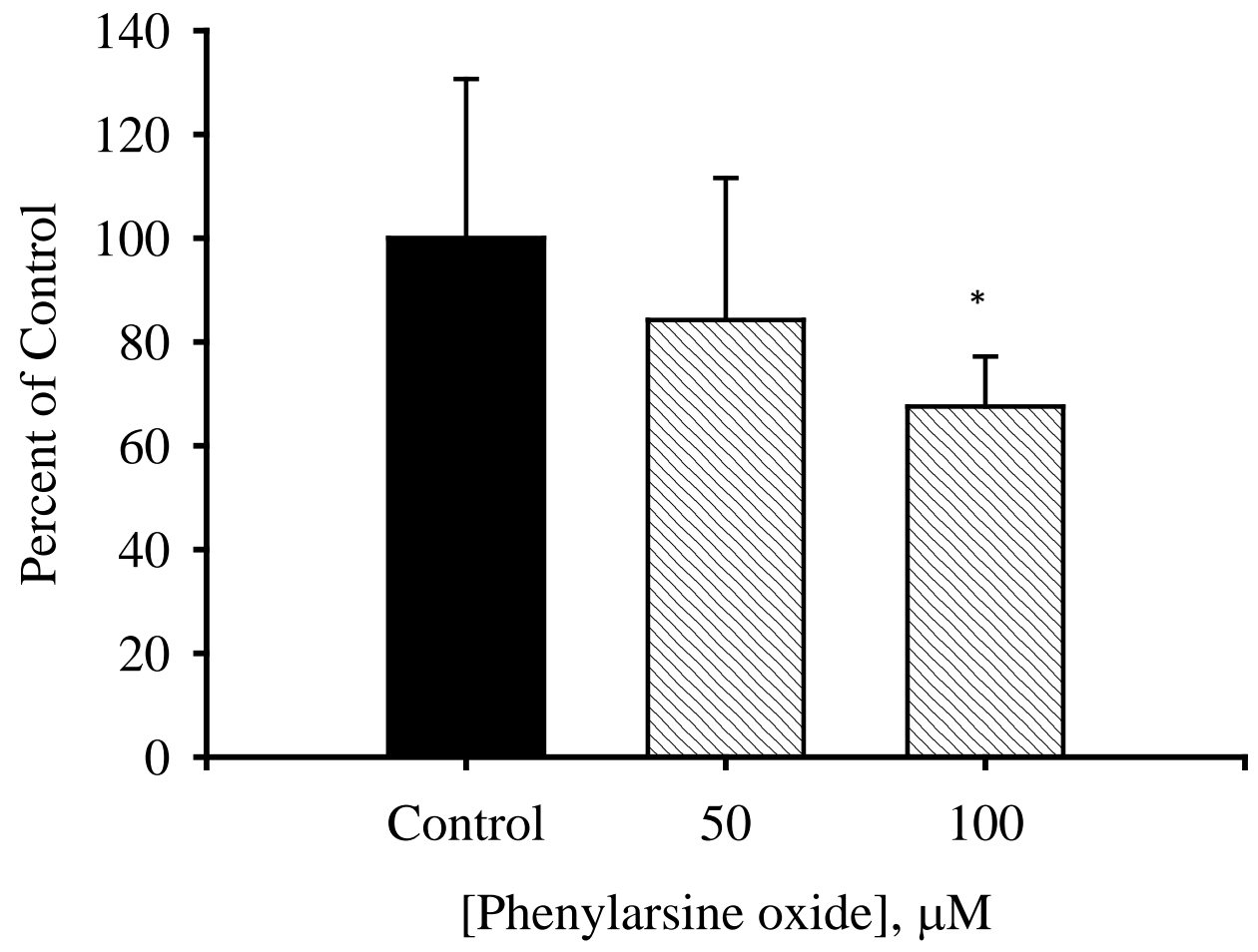


Rose, J.M. and Audus, K.L. (1998) Receptor-mediated angiotensin II transcytosis by brain mcrovessel endothelial cells. Peptides 19, 1023-1030. PMID: 9700750. Publisher's official version: <http://dx.doi.org/10.1016/S0196-9781(98)00054-0> . Open Access version: http://kuscholarworks.ku.edu/dspace/.

Rose and Audus

Figure 6C

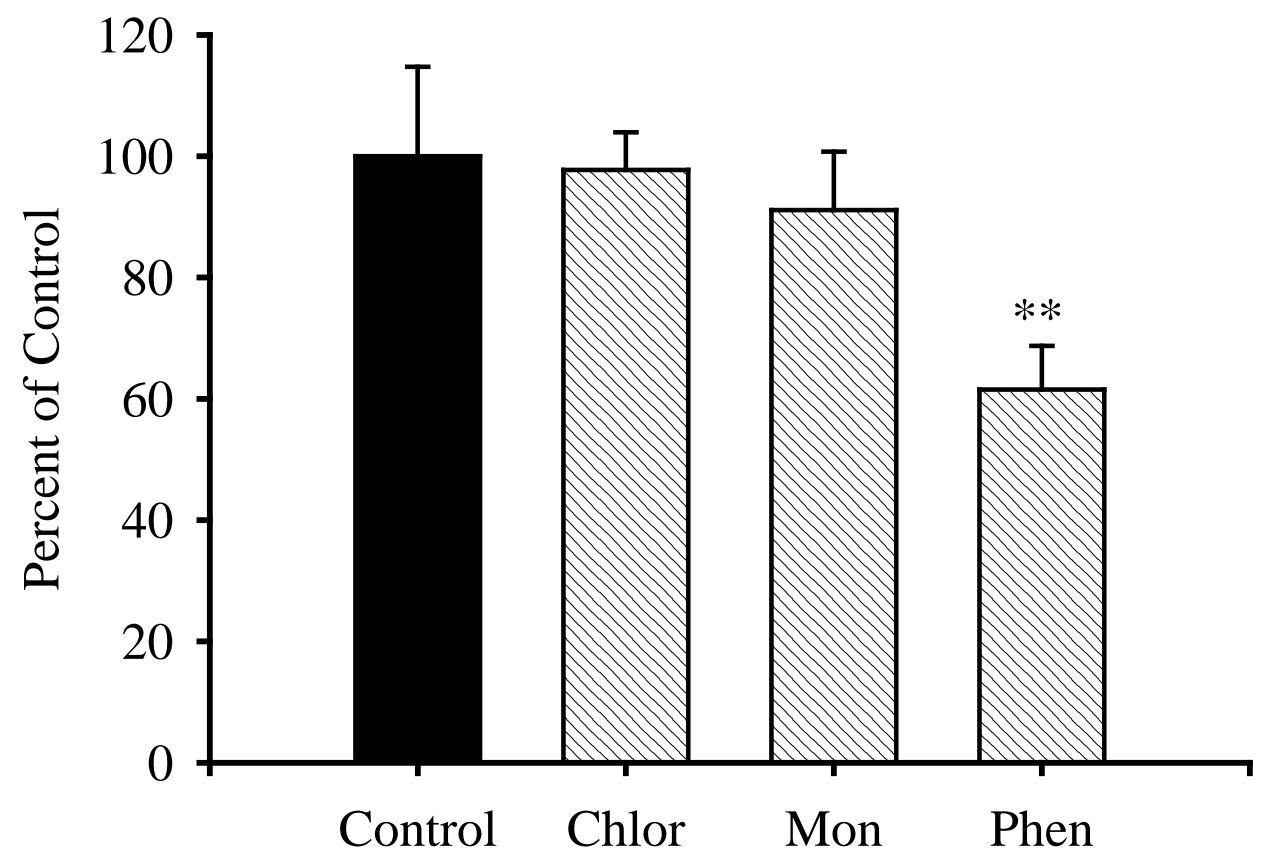

